\title{
The Body Move: Revising Portuguese Female Poetry of the First Quarter of the Twentieth Century
}

\author{
Isabel Pinto \\ Research Centre for Communication and Culture (the Catholic University of Portugal) \\ Faculdade de Ciências Humanas, UCP, Palma de Cima, Lisboa-Portugal. Orcid.org/oooo-ooo1- \\ 5033-9465. E-mail: vilhalpandos@hotmail.com
}

Received August 25, 2016; Revised December 15, 2016; Accepted December 20, 2016; Published January 14, 2017

\begin{abstract}
The first quarter of the twentieth century in Portugal was characterised by a series of important historical and political events: the Regicide ( $1^{\text {st }}$ February 1908), the fall of the Monarchy and establishment of the Republic ( $5^{\text {th }}$ October 1910), and the First World War (1914-1918). By this time, women could not yet vote and they were systematically ignored in the debate of crucial social issues. Therefore, the main question here addressed is how poetry as free embodiment can take part in a gender revolution, promoting the feminist turn. The answer lies in the consequent breakout of female sentimental literature, which entitled women to reveal themselves, by enabling the poetic scrutiny of their intimacy through a particular focus on the body as prime referent. In this way, they dared to expose dreams, desires, fulfilments and despairs, firming an identity pact through poetry, and engendering a collective voice with social meaning. The published poems here analysed convey the idea that being a woman was something valuable and unique, and, at the same time, manage to inscribe female poets such as Virgínia Vitorino and Zulmira Falcarreira in the Portuguese intellectual mainstream.
\end{abstract}

Keywords: twentieth-century poetry; women; gender; body; feminism.

\section{Introduction}

In 1845, Margaret Fuller looks at the differences between men and women in order to claim that women need their intellectual and spiritual resources reinforced. As a conclusion, Fuller argues that each person must be a self-dependent individual. For women to become such individuals, men need to withdraw their dominance, but women themselves must also be able to proclaim their self-dependency. By the late nineteenth-century, the American New Woman (Tóth, 2005) and the European Garçonne (Vaquinhas, 2013: 128-129) brought along visual depictions of a feminist ideal that was to have a deep influence on women's social awareness as an active participant and working force in society. Both the New Woman and the Garçonne broke with the traditional image of women, submissive and domestic, by presenting and endorsing the independent modern woman at one and the same time.

Nevertheless, as Esteves (2001) points out, by the beginning of the twentieth century, women in Portugal could not yet vote (in fact, the government explicitly inhibited women from

\footnotetext{
(C) AesthetixMS 2016. This Open Access article is published under a Creative Commons Attribution Non-Commercial 4.0 International License (http://creativecommons.org/licenses/by-nc/4.o/), which permits non-commercial re-use, distribution, and reproduction in any medium, provided the original work is properly cited. For citation use the DOI. For commercial re-use, please contact editor@rupkatha.com.
} 
voting through a law dated from $3^{\text {rd }}$ of July 1913, only dismissed in 1931), a great majority didn't have access to education (the 1911 census established $75 \%$ of illiteracy amongst the Portuguese population) and neither to a professional career. The participation of Portugal in The First World War, in 1916, caused increased economic problems, with the weakening of republican identity. By that time worldwide changes and great social issues dominated the international agenda.

In fact, the Portuguese Civil Code of 1867 still shadowed women's social position (Vaquinhas, 2013). This Civil Code established women's compulsory obedience to the husband, since, for instance, she ought to accompany the husband in every social occasion, and could not publish or pursue a career without his prior agreement. But with the end of the monarchy, and in the context of a new republican regime, issues like the civil marriage and the right to vote were getting increasing public attention. This new national context, along with the rapid development of the press, telegraph and post, made it possible for a more rapid contact with the international trend (Vaquinhas, 2013: 139).

In this time of change, several feminine associations appeared, such as "Comissão Feminina pela Pátria" [Feminine Commission for Homeland], in 1914, and "Cruzada das Mulheres Portuguesas", [Portuguese Women Crusade], in 1916, and, correspondingly, a significant number of feminine periodicals started to gain its way: A Esperança: Semanário de Recreio Literário Dedicado às Damas [Hope: Weekly Literary Amusement for the Ladies], in 1868; Almanaque das Senhoras para Portugal e Brasil [Ladies' Almanac for Portugal and Brazil], in 1871; Alma Feminina [Feminine Soul], in 1917; Eva: Jornal da Mulher e do Lar [Eve: Woman and Home Newspaper], in 1925; Portugal Feminino [Feminine Portugal], in 1930, just to name a few of them. In fact, the link between women and literature is first straightened and developed within this kind of publication. Women were standing for the right to participate in the social debates of their era through numerous columns of opinion, articles, reviews, and also poems. The press was the most consistent path to a better and fairer world, where women could finally afford a personality of their own. More and more, a few educated women, with contacts among Spanish and French activists (Esteves, 2001: 87), insisted on expressing themselves, looking for their unique and personal voice to convey the richness of female world, so as to affirm, little by little, that being a woman was something to be proud of, and thus not to be silenced at all:

...na imprensa, a partir de 1906, encontram-se com regularidade reflexões sobre o feminismo. Aí encontraremos Albertina Paraíso, Ana de Castro Osório, Lucinda Tavares, Maria Veleda e Virgínia Quaresma, tendo a temática feminista passado a fazer parte do conteúdo de diários como $O$ Mundo e Vanguarda. Os textos dedicados ao feminismo pelo "Jornal da Mulher", secção iniciada em 1906 no periódico O Mundo, e da responsabilidade de Albertina Paraíso, permitem compreender o que reivindicavam as feministas Portuguesas e o que se passava no final da Monarquia. Por exemplo, a Vanguarda, diário republicano independente, inclui, em 1906, a secção "Galeria feminista", criada após a apresentação da Secção Feminista da Liga Portuguesa da Paz (Silveirinha, 2012: 170; unless indicated otherwise, all translations are mine).

[... in the press, from 1906 on, there are recurrent reflections on feminism. There we will find Albertina Paraíso, Ana de Castro Osório, Lucinda Tavares, Maria Veleda and Virgínia Quaresma, as the feminist issue gains ground on daily newspapers such as The World and The Avant-garde. The texts dedicated to feminism by "Woman Newspaper", section initiated in 1906 in the periodic The World, with Albertina Paraíso as responsible, spread the word about the Portuguese feminist claims and what was going on at the end of the monarchy. For instance, The Avant-garde, an independent republican diary, includes, by 
1906, the section "Feminist Gallery", created after the presentation of the Feminist Section from Portuguese League for Peace.]

In fact, from 1915 to 1925 , a group of female poets was entrenched in the press on a regular basis, electing the sonnet as favorite poetic form. The group included Virgínia Vitorino, Amélia de Guimarães Vilar, Marta de Mesquita da Câmara, Zulmira Falcarreira and Florbela Espanca, etc. Then, several of them would see their poems edited in a monograph, with even a few sponsoring their own publications, like Amélia de Guimarães Vilar (O Meu Rosário [My Rosary], 1920). Some of these editions were quite successful, e.g. Virgínia Vitorino's Namorados [Boyfriends] (1920). All these female poets, with the exception of Zulmira Falcarreira, are included in a Portuguese feminine anthology, Dicionário no Feminino [Feminine Dictionary] (2005), where the social, cultural and educational accomplishments of several women are recognised in a correspondent biographical entry. Reading the entries, the common ground between the lives of these female authors becomes clear, since they all started writing in the press, they all wrote poetry and adopted the sonnet as major form. Additionally, they all received an education and had professional careers of their own. In fact, Amélia de Guimarães Vilar was an accountant, Marta de Mesquita da Câmara a journalist, and Virgínia Vila Nova de Sousa Vitorino a successful actress.

Therefore, our main goal here is to fully contextualise the burst of female sentimental poetry in Portugal, driven by New Historicism as framework, in order to argue for the relevance of this kind of poetry for the feminist cause, taking up three 'forgotten' texts. This effort has not yet taken place, mainly because of the general assumption that this poetry is literarily unworthy (e.g. Pereira, 1983). As a matter of fact, in our opinion, this argument has long overshadowed the contribution of a group of poets to a new social awareness regarding women's rights and needs.

\section{Embodying Poetry: Body depiction and Gender Emancipation}

In recent studies the representation of the body has assumed particular relevance in the construction of female identity across literary genres and within different historical periods, as to establish new historical criteria for gender divisions and social changes (Curti, 1998; BabanaHampton, 2002; Ferfeli, 2011; Ruiz, 2012).

From the late nineteenth century to the beginning of the twentieth, there was a big change in the image of women. The concept of femininity was dissociated from the traditional image of the housekeeper to embrace fashionable trends, with a new modern look emerging. In Portugal, for instance, the Garçonne was the leading ideal of beauty and good looks. The Garçonne look consisted of short hair, short skirts and a defying, independent and bold attitude (Vaquinhas, 2013: 128-129). This visual depiction of the modern woman was much critised, because it brought along serious changes to how women related, and tried to articulate, their private and public lives. The Garçonne implied an increasing detachment towards house work, and, simultaneously, great involvement in public entertainment, like parties, balls, and shows. In this way, the role of women as home guardian was put in question, and their public visibility and exposure was becoming a fact. Women were coming out of the shell, claiming a new awareness regarding their femininity and the different ways of living it. It is amidst this social and cultural atmosphere that the body comes to play a key role. New meanings are placed upon the female body insofar as it is used in a new set of contexts and situations.

So, in order to fully understand the social impact of those poetic testimonies, one must also account for women's daily life in the society of the time, i.e. "the sphere of her sex" (Fuller, 
2008 18). Namely, in high society, women's life was, on the one hand, a granted succession of mundane amusements, like going out to the opera or to the theatre, leading to an increased exposition of the body, and, on the other hand, women still spent a considerable amount of time in domestic affairs, this way engaging in the reclusion of the body. The suggested contrast 'exposition/reclusion' is liberated, in general, by others such as 'decay/resettlement', desire/reason and 'real/unreal', all bursting out in female poetry as images of a claiming body, fully aware of the social restrictions imposed on it.

Therefore, body references, making its materiality explicit, play a very significant role in a certain literary momentum, in Portugal, as the ultimate medium for a feminine way of life and its most inherent feelings. Translating women, by a part-whole relationship, the body is depicted in detail. Hence, in the poems of the mentioned female authors, the reader can find lips, kisses, blood, abandoned bodies, hands, faces, asking for confrontation, in a subtle assumption of sexuality. Butler (1993: 1) asks 'Is there a way to link the question of the materiality of the body to the performativity of gender?'. These poetic testimonies are based on the depiction of the materiality of the female body, absorbed by an array of actions taking place in a parallel dimension to the real world. Thus, the poem is the needed platform to link the materiality of the body to self- awareness through performance. The parts signifying the body are displayed as objects of discovery of the yet unknown world of femininity. In their attempt to assert for a renewed landscape, with its bodily pathways, they trigger an identity, i.e. an idea of 'self. Power, sex, and body materiality are so overtly codified that gender is no longer the issue, being replaced by a feminine perspective on life and death. If “"sex" is from the start normative' (Butler, 1993: 1) what these poems want to evade, by endorsing an identity dynamics, is precisely the normative effect, responsible for the diminished role of women in society for a too longer time. Although 'sentimental', i.e. minor, according to literary critics (e.g. Pereira, 1983), the poems reveal the materiality of the body within the inner world of feminine thoughts and feelings, that side by side structure the poetic discourse. From this tension between material (the body) and immaterial (thoughts and feelings), results the assertive response of a projected 'I'.

Performing their femininity in various ways, disclosing as many body actions and reactions as possible, these female poets called for a more active role regarding their own lives and society in general. Melo (2009: 2) states the following about the poetry of Florbela Espanca, the only of these female poets to receive some attention from literary criticism:

Tem-se dito que o sujeito feminino na poesia de Florbela recusa a condição de objecto e afirma sua condição de protagonista activo. Talvez a manifestação mais evidente desse processo de afirmação dos poderes do sujeito feminino resida na tomada de consciência do corpo, que, na sua sensualidade e erotismo, afirma a força de Eros.

[It has been generally assumed that the female subject in Florbela's poetry refuses the object condition by claiming a main character condition. The most powerful manifestation of this female subject lies maybe in the awareness regarding her own body, which assumes the strength of Eros, through sensuality and eroticism.]

This kind of sentimental poetry relied on the body as central signifier on the threshold of a world of intimacy and feminine display. The poem was to be assumed as an endeavour towards bodies making a display of themselves (Foucault, 1978). In this sense, sexuality broke free from its silent confinement, and women reacted to the repression imposed on them, defying the nineteenth-century dominant trend of verbal decency and constraint (Foucault, 1978). 
Thus, through poetry women could legitimate their own subjectivity by appealing directly to a distinctive way of codifying the world and reacting, in their own terms, to what was happening around them and to them. In a society where law still abounded woman's obedience to the husband, poetry was used as an instrument to probe the effects of a feminine 'self as a road to full citizenship:

Nas sociedades sedentárias que permitiram a acumulação de riqueza, os homens, pela sua força física em regra superior, ocuparam-se do gado e das tarefas agrícolas, vindo a controlá-las. A guerra era feita tendencialmente por homens, permitindo o seu adestramento e o seu acesso a funções públicas de índole militar. Porventura mais grave, num círculo que se quebraria apenas no século XX: a cultura era disponibilizada, em primeira linha, aos homens, com um relevo particular para o ensino e o estudo do Direito. Ficava a mulher remetida para lides domésticas e para a educação dos filhos de mais tenra idade: desempenho, de resto, prejudicado justamente pelo problema cultural. A inferioridade física, económica e, depois, cultural, da mulher, teve reflexos jurídicos até, praticamente, à segunda metade do século XX (Cordeiro, 2011: 65).

[In sedentary societies that allowed the accumulation of wealth, men, due to their superior physical strength, in general, were responsible for the cattle and other agricultural tasks, becoming in charge of this outside work. The war was essentially made by men, allowing for military training and access to military public functions. Possibly even more serious, in a circle that would only be broken in the twentieth century, culture was mainly available to men, especially in the teaching area and in the field of law. Women were assigned the domestic activities and the education of the younger sons, in which their performance was conditioned by cultural deprivation. The physic, economic, and, afterwards, cultural inferiority of women had legal counterparts that lasted to the second half of the twentieth century.]

As the quotation above well documents women's discrimination lied dominantly in their segregation from culture. Women's dependency was mainly a result of impediments faced when trying to access proper education and full cultural enjoyment (Cordeiro, 2011: 69):

O grande óbice à igualdade dos sexos residia na falta de cultura e de instrução da mulher. Desde que se foi estabelecendo a escolaridade obrigatória para homens e mulheres e que se consumou, ao longo da primeira metade do século XX, o acesso das mulheres ao ensino secundário e ao superior, a igualdade impôs-se, pela base.

[The major obstacle to gender equality lied upon women's lack of culture and instruction. From the moment that mandatory education was a requisite for men and women alike, and, that from the first half of the XX century, women could have access to secondary education, and to a college education, equality came through quite naturally.]

As a matter of fact, as late as 1946, Plínio Salgado (1946: 59-60) still maintained that education was of minor advantage to women, because, in his perspective, an educated woman without religious feelings was less capable than a peasant. The author argued that, on the one hand, women's greatest aims depended upon an irreprehensible honour, and, on the other hand, women possessed an unhealthy curiosity, that, untamed, would surely lead to their irreparable loss:

Antes, pelo contrário: a mulher ilustrada, mas sem formação moral e religiosa, torna-se mais incapaz do que uma camponesa analfabeta de defender os seus legítimos interesses 
tão intimamente relacionados com a sua honra. Levada por doentia curiosidade e cheia da presunção de que nada lhe acontecerá de mal, deixa-se levar muito mais facilmente do que os homens pela sedução do «algo novo» e pelo anseio das experiências pessoais.

O homem é mais tímido, confia menos em si próprio, opõe sempre reservas e restrições às teorias que o atraem; a mulher, mais impulsiva, ao mesmo tempo que cede aos primeiros estímulos da novidade, entrega-se, dá-se inteira, tanto ao bem como ao mal, o que é uma condição mesmo da passividade inerente ao seu sexo.

A força, por conseguinte, mantenedora da personalidade na mulher há-de ser a sua formação moral e a formação moral só tem uma base segura: o sentimento religioso.

[On the contrary: the illustrated woman, without moral and religious insight, becomes more incapable than an illiterate peasant of defending her own legitimate demands, so closely related to her honour. Taken by her ill curiosity and so full of the presumption that nothing bad could ever happen to her, she is carried much more easily than men by the attraction of 'something new' and for the longing of personal experiences.

Usually more shy, a man trusts less in himself, opposing systematical restrictions to whatever theories may attract him. By contrast, a woman, more impulsive by nature, as she gives away at the first glimpses of novelty, equally indulges in good and in evil, which is closely related to the inherent passivity of her gender.

By consequence, the strength that maintains a woman's personality must be her moral education, and moral education can only have one solid base which is the religious feeling.]

The argument that women's condition was inherently passive must be underlined, as this passive bias has long been emphasized across fields and disciplines, literature, theatre, civil rights, social conventions, sexual perspectives, etc. Flora (1971), in a comparative study between North American and Latin American women, corroborates the continuum of women's assimilation to a passive being, but manages to go beyond that by situating it within the dynamics between oppressor and oppressed:

Passivity seems to be a cross-cultural trait of oppressed groups. According to Memmi (1968) oppressors develop a "racist ideology", which assigns character traits to the oppressed as an expression of the objective situation of the oppressed group. If members of a group occupy an inferior social position over time, members of a high status group justify their status by assigning so called "innate" characteristics to the inferior groups. Because the high status groups are generally the significant others for the oppressed, they use the socially-assigned "innate" characteristics in their definition of self (p. 435).

Baring in mind Salgado's statements about the female condition, women can easily be viewed as an oppressed group, whereas men maintain their dominance by systematically conveying 'authorised' portraits of women as the Other, allegedly certified by their 'innate' characteristics.

\section{Poems of Unruly Bodies}

It is easy to draw a parallel between the negative judgment, and poor opinion, contained in the Portuguese (Pereira, 1983: 872-873) and American critics' discourse about these women poets (Bennett, 1995: 202): 
One of the truisms of American literary criticism is that nineteenth century magazine verse especially that by women, served as filler for editors burdened with random amounts of space at the ends of articles and stories. On this basis, critics have dismissed the ubiquitous presence of women's poetry in national and regional periodicals, particularly in the second half of the century, as lacking substantive significance. When the quality of these poems is discussed at all, it is usually to support early modernist contentions that American poetry was in a parlous state as the century drew to a close.

We shall then assume that the same poetic movement took place in several countries, with little differences in time. In the United States of America the magazine feminine verse dominated as early as the second half of the nineteenth century. Other studies indicate that this literary momentum was also taking place in Brazil (Oliveira, 2009) and in Great Britain (Craciun, 2009). As a matter of fact, as early as 1799, in Letter to the Women of England on the Injustice of Mental Subordination, Mary Robinson stated:

The press will be the monuments from which the genius of British women will rise to immortal celebrity: their works will, in proportion as their educations are liberal, from year to year, challenge an equal portion of fame, with the labours of their classical male contemporaries (p. 82).

Despite the critics' dismay, Portuguese and otherwise, the main idea to be stressed is that the so-called "sentimental literature" had a decisive role in a more large feminist movement. Therefore, the poems produced demanded social awareness in relation to women's condition. As said before, the conveyed testimonies of intimacy relating to everyday life, more than regulating sexual and gender differences, were prone to establish a new identity. From the amorphous mass of indistinct women, all silent, passive and socially constrained, singularity emerged through the fixed form of the sonnet, by disclosing a unique interaction with the world.

At the time, one of the most popular and well-known of these female poets in Portugal was Virgínia Vila Nova de Sousa Vitorino (1895-1967). She became a successful actress and playwright with several plays (Degredados [Banished], A Volta [The Turn], Fascinação [Fascination], etc.) staged at the National Theatre D. Maria II during the Thirties (Castro and Esteves, 2005: 896) . However, her big hit was her first volume of poems Namorados [Boyfriends] (1920), which was edited fourteen times, twelve in Portugal and two in Brazil. It received general acclamation, and pleased both critics and readers in general (Castro and Esteves, 2005: 896).

Virgínia Vitorino had some public interventions relating directly to the feminist cause. For instance, in an interview to the newspaper Diário de Lisboa [Lisbon Daily], in November 1929, she stated that it was not enough for women to be feminine for they should also be feminist (Castro and Esteves, 2005: 897). By doing this, she explicitly engaged in a feminist discourse, encouraging women to adopt a new attitude towards themselves and society.

The first poem here analysed is from the book Apaixonadamente [Passionately] (1923), Vitorino's second volume of poems, which was published six times:

BRUMA

Não sei quem anda a perseguir-me os passos

N'esta amargura enorme em que me agito.

Ergo os braços, em ânsia de infinito,

E sempre encontro fim para os meus braços. 
Desce ao meu rosto de orgulhosos traços

A rigidez amarga do granito.

Olho as estrelas uma a uma, e grito

À imensidão solene dos espaços...

Toco o império divino da loucura,

E subo tanto, a uma tão grande altura,

Que nem tu, minha sombra, lá me atinges!

Se alguém me busca, eu vou mais alto logo.

E se estonteada, às vezes me interrogo,

Sinto em mim o silêncio das esfinges!... (p. 16)

[MIST]

[I don't know who is haunting my steps

In this deep sadness that makes me restless.

I lift my arms, searching infinity,

And I always find an end to my arms.

It goes down to my face of proud traces

The bitter stiffness of granite.

I look into the stars, one by one, and I shout

To the solemn immensity of the spaces...

I touch madness divine empire,

And I go up so much, to such big altitude

That not even you, my shadow, can reach me there.

If someone is looking for me, I go immediately higher.

And if dizzy, I sometimes question myself,

I feel in me the silence of the sphinxes.]

In this poem, we would like to point out how much of the body is conveyed so that the wandering persona can fully express a striking vagueness of state and feelings, within a mist of infinity and unbounded landscape. All the movement pursued by the persona is emphasised by the great contrast called upon her by "the silence of the sphinxes" of the last, concluding verse. So, there is a contradiction at stake that revolves around the shout of the body and the silence of an analytic voice, the voice of reason, also reinforcing oppositions such as "desire/reason" and "real/unreal". The body must be set lose to truly free the mind.

According to Foucault (1978: 78), our society is under the sign of sex, favouring a "logic of sex", rather than a "physics". As a series of binary oppositions (body/ soul, flesh/ spirit, instinct/ reason, etc.) has come forth linking sex to mechanics devoid of reason, the West has succeeded not merely in assimilating sex to a field of rationality, but to put "our bodies, our minds, our individuality, our history" under a logic of concupiscence and desire. Nevertheless, assuming that Vitorino's poem enacts that logic leads us to a somehow productive analysis of to what extent, in a particular historical period, the dominant logic of concupiscence and desire was used and enforced by feminists. 
By the late nineteenth and early twentieth century women's claim for a logic of desire was, in fact, something new in terms of feminine discourse and ideology. The search for enacting desire is what exhales the poem's persona, leading her to escape her own shadow. The poem's persona seeks "infinity", "immensity", "divine empire", "big altitude", but somehow feels trapped by her frenzy and deep sadness.

The lyric subject feels unsatisfied with the present state and condition, as she senses that someone is tracking her down, and tries to achieve freedom through bodily responses. Hence, it is this pulsing body that inflicts frenzy on the reader itself, somehow forced to look for a way out through the poem. Foucault (1978) debating the link between power, knowledge and sexuality, considers that freedom will only be achieved by "a transgression of laws, a lifting of prohibitions, an irruption of speech, a reinstating of pleasure within reality" (p. 5). We can see all this in the poem, since the lyric subject refuses to compel to a normalised state of affairs, rebelling against the concealment of feminine identity and its quest, by engaging in irruption of speech and embodiment.

The second poem, also from de previous book, is "Salomé":

SALOMÉ

Olha-se a furto, inquieta, nos espelhos

Que lhe reflectem a beleza e a graça...

E sacode, fremente, quando passa,

As anilhas de prata dos artelhos...

Ergue-se toda e logo cai, de joelhos.

Os perfumes são quentes; a luz baça...

E aquele corpo já não anda, esvoaça

Sobre os tapetes flácidos, vermelhos...

E corre sempre! Tilintando, as contas

Como serpentes perturbadas, tontas,

Cingem-lhe os braços, o pescoço, a trança.

Desmaiam chamas... Vai surgindo a lua...

Deusa do ritmo, Salomé, flutua,

E ri, n'um grande riso, e dança... dança...

[SALOME]

[She looks at herself, from aside, uneasy, in the mirrors

Reflecting her beauty and grace...

And shakes, restless, when passing,

The silver rings on her ankles...

She rises and immediately falls, on her knees.

The perfumes are warm; the light pale...

And that body no longer wanders, but flies

Just above the flaccid red carpets... 
And she always runs! The tinkling beads,

Like distressed snakes, dizzy,

Fold her arms, the neck, the twist.

Flames dismay... The moon makes her appearance...

Goddess of the rhythm, Salome, floats,

And laughs, with a big laugh, and dances... dances...]

All the description of Salome, the historical dancing figure from the New Testament (Mark 6:17-29, and Matthew 14:3-11), is based on body referents, as the poem addresses the "new woman", i.e. the glamour silhouette that goes around dancing and spreading her grace and charm. This woman dominates the surroundings by never stop dancing, relying on her body to enact and react to daily life, giving rise to a form of spectacle. The seductive power of Salome is based on a well diversified body performance, encompassing rise and fall, wander and fly, run and float, but mainly consists of everlasting dance, inevitably attracting the gaze of others. The spectator either corresponds or submits to that almighty body, as even snakes go dizzy and flames weaker, with the moon also coming to assist the goddess of rhythm.

Salome spreads her womanliness everywhere, seducing the world with her beauty and grace. The poem takes Salome as a sex stereotype to its limits, because she is depicted as completely self-centered, enacting her seductive impulses through a non-stop dance, and the result is her dominance over whatever remains beyond her. Therefore, her dance, overcoming and annihilating whatever she encounters, can also be interpreted as a well succeed attempt at artistic expression.

Marcus (1974: 106) analysing Salome (1894), the play by Oscar Wilde, underlines her power over a repressive society:

The characters of both Hiordis and Briinnhilde, derived from the Nordic myths, suggest, like Salome, that witches were women betrayed by love, and that they were anarchists and destroyers of the men and societies which had kept them prisoners of their own bodies. The message of Wagner's Ring, Ibsen's plays, and Wilde's Salome is that love and death are intimately connected in a repressive society.

The Salome of the poem, alike the one in Wilde's play, embodies the power of destruction regarding a society where women were systematically undermined. In this sense, it turns out that the seductive magic of her dance can annihilate whatever restrains her from self-expression. Furthermore, in both texts, Salome is presented as an object of male desire, and she is characterised, on the one hand, as an innocent girl and, on the other hand, as a sexually-aware woman, with her ambiguity strongly linked to the symbolism of the moon. In fact, the association between the character of Salome and the moon, introduced by the poem's last stance, is present throughout Wilde's play (Tabak, 2005: 163):

Wilde uses the play's symbolism to further convey his criticism of prejudiced views in general, and of those regarding women in particular, and so, like the other images of the play, the moon suggests a dual meaning. On the one hand, it is an independent, removed object, seemingly irrelevant to the play's progression, but on the other hand, with every character narrating it differently throughout the play, it becomes very personal and idiosyncratic.

Nevertheless, what is most at stake in the comparative approach between Vitorino's poem and Wilde's play is how Salome was used as a symbol in literature to 
convey an array of new meanings and attitudes concerning the role of women in early twentieth-century society.

The last poem here analysed is from Zulmira Falcarreira (1867-19??). Barely known as an author, Falcarreira was born in 1867 , in Rio de Janeiro. Her father was Pompílio Augusto Gonçalves Franco, viscount of Falcarreira, and her mother Carolina Augusta Ferreira d'Almeida, viscountess of Falcarreira. She published her poems in several newspapers, namely Ilustração Portuguesa [Portuguese Illustration], A Mulher [The Woman] and Diário de Notícias [News Daily]. She wrote under the pseudonym "Blue". Although she is a "forgotten" author at the present, Cardoso (1917) in his anthology of Portuguese female poets does include her, underlining her poetic accomplishments and announcing a big publishing project that would encompass the totality of Falcarreira's works (p. 41). The next poem, "Na Vinha" [In the Vineyard] is from a manuscript, still unpublished, Asas Libertas [Free Wings], from 1922:

\section{NA VINHA}

Outubro: ao meio-dia - Outono em fora

Sob a guarda de um clima temperado, Fomos dar o passeio costumado, Gozando d' alegria d' essa hora:

Em toda a vinha a cor mudou agora E no seu grande corpo abandonado Sangra, rubra de dor, de lado a lado, Sangra a angústia dos cachos que ela chora:

Nós, caminhando a par, notámos cedo Que tínhamos os dois algum segredo Alguma grande mágoa inconfessada...

E entrelaçando as mãos e unindo o rosto, Deixámo-nos ficar até o sol-posto, Olhando para a vinha ensanguentada.

\section{[IN THE VINEYARD]}

[October, noon, Autumn outside

With the mild climate as guardian, We went for the usual walk, Enjoying the hour's happiness.

Throughout the vineyard the colour has now changed And in her big abandoned body Bleeds, scarlet from the pain, from side to side, Bleeds the anguish of the bunches that she cries.

We noticed early, walking side by side, That the two of us had some secret Some big, unrevealed sorrow... 
Interlacing hands and bringing our faces together, We let ourselves be until the sunset, Looking at the bleeding vineyard.]

In this last poem, the vineyard embodies the state of mind of the wandering lovers. For that, the vineyard is conveniently personified, through a sequence of body metaphors. As a matter a fact, the first and general view of the vineyard is as a "big abandoned body". The personification gets stronger by the use of very vivid images ("Bleeds, scarlet from the pain, from side to side", "Bleeds the anguish of the bunches that she cries") relying on the repetition of "bleed". The vineyard is agonizing, just like the lovers, who struggle with secrets and silenced feelings. In this poem, nature is a very sensitive body to the extent that it reproduces and echoes the feelings of those that wander in uncertainty, bleeding just like them. The nature's function as speculum is based on the image of a great agonizing body that does not seek for cure or redemption.

Alaimo (2000) focus on the problematic relationship between woman and nature, from a feminist point of view, acknowledging the fact that as 'nature has been at the heart of a plethora of misogynist arguments and ideologies, grappling with the concept of nature has been an extraordinarily important component of feminist thought' (p. 6). A possible solution to the entanglement involving nature and woman can actually be the redefinition of nature. In this sense, nature should no longer mirror the dominant masculine culture that restates the same cultural and social values that objectified women as passive subjects by nature (Alaimo, 2000: 10):

If nature is no longer a repository of stasis and essentialism, no longer the mirror image of culture, then the female body need not be misogyny's best resource. Disrupting the opposition between nature and culture opens up spaces for feminisms that neither totally affirm nor totally deny difference. Feminism can instead cobble together a myriad of adulterated alternatives that neither seek an untainted, utterly female space outside of culture nor cast off bodies, matter, and nature as that is forever debased.

According to this view, Falcarreira's poem by depicting the vineyard as a bleeding abandoned body succeeds in suggesting the overwhelming nature of the feminine body. In this way, what nature mirrors is the cultural tendency for women's increasing exposition through images of the body. The feminine body shall no longer be concealed and undermined, since women are entitled to an identity that comes directly from the uniqueness of their body. Falcarreira's poem thus opens a new space for feminine disclosure by depicting nature as an extended body without redemption.

The three poems are body-centered to the extent that the subject coherently relies on images of a restless, greatly exposed body searching for its place in a male world, where its confinement had long been the rule. In this context, sentiment and emotional intensity are of less importance, when compared to the spectacular display of the female body by the beginning of the twentieth century (Tóth, 2005: 257):

A significant shift took place in the emotional culture, as well. While for Romantics and Victorians, sentiment and emotional intensity were highly valued, by the beginning of the twentieth century they lost their significance and physical appearance gained importance. This phenomenon was also signaled by the fact that femininity became a spectacle by this time, meaning that women's bodies were presented and "reproduced" in journals and magazines. 
The fact is that poetry also took part in this broader tendency for the exposure of the female body. By insisting on a body that mediated the relationship between the feminine and the world, poems like the ones here presented called for cultural and social change towards the status of that same body. Hence, feminism has long elected the body as fundamental motif for not compelling to a male social order (Price and Shildrick, 1999: 1): "feminism has long seen its own project as intimately connected to the body, and has responded to the masculinist convention by producing a variety of oftimes incompatible theories which attempt to take the body into account".

Notwithstanding, in the poems here presented the images of the body conveyed are not in the least straightforward, for they resonate the complex relationship between woman and her body. The body depicted through an array of binary oppositions is never presented as a solution. Differently, women's ongoing search for their place in a subverted world depends on a fearless body, one prone to unruliness when facing the threat of submission. Therefore, the feminist path of these Portuguese female poets mostly entails a representation of the body as an instrument for radical enactment, rather than a given solution for women's dilemmas.

\section{Conclusion}

The analysed poems respond to the question of what means to be a woman. In showcasing women's particular way of experiencing the world, they endorse women as a specific referent and subject. This poetic emancipation leads the way to a new mentality. For a start, women are challenged not to see themselves seating in an armchair, doing the dishes or accompanying their husbands to the theatre, but in a new settlement, where their feelings, states of mind and body experiences count, and can even be transposed to artistic self-expression. The body depicted by these female poets is not at all passive. It comes as the ultimate medium to express feminine aims, feelings and desires. Furthermore, it is also a bleeding body in the sense that it shows no fear of exposing intimacy, with its weaknesses and dismays.

More than just "feminine literature à la garçonne" (Pereira, 1983: 872), and intentionally dislocating the discussion from a merely literary standpoint, this poetry argues and adds something to the body's major importance in feminist theory: "Theories about the sexuality of the body, power and the political control of women's bodies by patriarchy, are central to feminism" (Humm, 1999: 26-27).

From its beginning the feminist movement in Portugal, and elsewhere, called for a new awareness of women's needs, and that necessarily meant to take the female body into consideration. Thus, what cannot be ignored is that feminism was a way to respond to worldwide social changes. In fact, Margaret Fuller (2008: 319) acutely formulates the need for a "new woman": "Society is now so complex, that it is no longer possible to educate Woman merely as Woman; the tasks which come to her hand are so various, and so large a proportion of women are thrown entirely upon their own resources". The freedom exhaled by poems of the feminine, as an example of the liberating power of poetry, was to take the lead in terms of envisioning new exploring pathways for women, helping to redefine the Western thought to its bare ontological foundations. 


\section{Works Cited}

Alaimo, S. 200o. Undomesticated Ground: Recasting Nature as Feminist Space, Ithaca: Cornell University Press.

Babana-Hampton, S. 2002. Literary Representations of Female Identity: Feminisms in Arab-Muslim Societies and Clashing Paradigms on Conceptions of Modernity, Tradition, and Selfhood. The American Journal of Islamic Social Sciences, 19(4): 23-41.

Bennett, P. 1995. "Not just filler and not just sentimental: Women's poetry in American Victorian periodicals, 1860-1900". In Periodical Literature in Nineteenth-Century America, Edited by: Kenneth M. Price and Susan Belasco Smith. Charlottesville: University of Virginia Press.

Butler, J. 1993. Bodies that Matter, NY: Routledge.

Cardoso, N. C. 1917. Poetisas Portuguesas, Lisboa: Livraria Científica.

Castro, Z. O. and J. Esteves. 2005. Dicionário no Feminino (Séculos XIX-XX), Lisboa: Livros Horizonte.

Cordeiro, A. M. 2012. Divórcio e Casamento na I República: Questões Fraturantes como Arma de Conquista e de Manutenção do Poder Pessoal?. Revista da Ordem dos Advogados, n.o 1: 45-108.

Craciun, A. 2003. Fatal Women of Romanticism, Cambridge: Cambridge University Press.

Curti, L. 1998. Female Stories, Female Bodies: Narrative, Identity, and Representation, NY: New York University Press.

Esteves, J. 2001. Os Primórdios do Feminismo em Portugal: a 1.a Década do Século XX. Penélope, n.o 25: 87112.

Falcarreira, Z. 1922-1923. Asas Libertas; Asas de Ferro; Asas de Sonho (manuscript), 3 volumes, BNP Esp. A/6082-6084.

Ferfeli, P. 2011. Poetics of Identity: Mina Loy Voicing the Fluid Female Body, Frankfurt: Peter Lang.

Foucault, M. 1978. The History of Sexuality, Vol. I, trans. from the French by Robert Hurley, NY: Pantheon Books.

Fuller, M. 1845. Woman in the Nineteenth Century, NY: Greeley \& McElrath.

Humm, M. 1999. The Dictionary of Feminist Theory, London: Prentice Hall.

Marcus, J. 1974. Salomé: The Jewish Princess Was a New Woman. Bulletin of the New York Public Library, Vol. 78: 95-113.

Melo, C. 2009. Imagens do Feminino em Florbela Espanca. O Marrare, n.ํㅜ 10: 1-14.

Oliveira, K. 2009. Josefina Álvares de Azevedo: a voz feminina no século XIX através das páginas do jornal A Família, Rio de Janeiro: Fundação Biblioteca Nacional - MinC.

Pereira, J. 1983. Tempo neo-romântico (contributo para o estudo das relações entre literatura e sociedade no primeiro quartel do século XX). Análise Social, Vol. XIX (77-78-79): 845-73.

Price, J. and M. Shildrick 1999. Feminist Theory and the Body: A Reader. NY: Routledge.

Robinson, M. 1799/2003. Letter to the Women of England on the Injustice of Mental Subordination, Edited by: Sharon M. Setzer, Toronto: Broadview Press.

Ruiz, M. 2012. Women's Identities and Bodies in Colonial and Postcolonial History and Literature, Newcastle upon Tyne: Cambridge Scholars Publishing.

Salgado, P. 1946. A Mulher do Século XX, Porto: Tavares Martins.

Silveirinha, M. J. 2012. As mulheres e a afirmação histórica da profissão jornalística: contributos para uma não-ossificação da História do jornalismo. Comunicação e Sociedade, Vol. 21: 165-82. 
The Body Move: Revising Portuguese Female Poetry of the First Quarter of the Twentieth Century

Tabak, J. 2005. Medusa is no longer laughing: Oscar Wildés Sy m bolism in

Salomé. Journal of Theatre and Drama, Vol. 7/8: 161-75.

Tóth, Z. 2005. The (Im)morality of the New Woman in the Early 2oth Century. In Proceedings from the Eighth Conference of British, American and Canadian Studies, Brno: Masarykova univerzita.

Vaquinhas, I. 2013. História da Vida Privada em Portugal: A Época Contemporânea, Vol. III, Lisboa: Círculo de Leitores e Temas e Debates.

Vilar, A. 1920. O Meu Rosário, Porto: author's edition.

Vitorino, V. 1920. Namorados, Lisboa: Ilustração Portuguesa.

Vitorino, V. 1923. Apaixonadamente, Lisboa: Tipografia de O Sport de Lisboa.

Vitorino, V. 1926. Renúncia, Lisboa: Imprensa Lucas \& Ca.

Wilde, Oscar. 1894. Salome: a tragedy in one act, translated from the French of Oscar Wilde, pictured by Aubrey Beardsley, London: Elkin Mathews \& John Lane. 